BIOCYT Biología, Ciencia y Tecnología, 11(42): 789-791, 2018 (abril-junio)

ISSN: 2007-2082

http://revistas.unam.mx/index.php/biocyt

Publicada en la Facultad de Estudios Superiores Iztacala, Universidad Nacional Autónoma de México

\title{
FIRST HOST PLANT RECORD FOR ANASTREPHA AMPLIATA HERNÁNDEZ-ORTIZ, 1990 (DIPTERA: TEPHRITIDAE)
}

\section{PRIMER REPORTE DE PLANTA HOSPEDERA PARA ANASTREPHA AMPLIATA HERNÁNDEZ-ORTIZ, 1990 (DIPTERA: TEPHRITIDAE)}

\author{
María de Jesús García Ramírez ${ }^{1,1 \rrbracket}$, Enrique Antonio Hernández 1,2, Juan José Vargas Magaña 1,3, \\ Marvel del Carmen Valencia Gutiérrez ${ }^{2}$, Juan Carlos Chi Ruiz ${ }^{1,4}$ y Yamilé Placensia Valerio ${ }^{1,5}$ \\ ${ }^{1}$ Escuela Superior de Ciencias Agropecuarias de la Universidad Autónoma de Campeche. Calle 53 s/n. Col \\ Unidad Esfuerzo y Trabajo N. 2. C.P. 24350. Escárcega, Campeche. \\ 1,1凶migarcia@uacam.mx ,1,2anastrephaproject@gmail.com ,1,3jivargas@uacam.mx \\ 1,4 juancarlos1967@live.com.mx ,1,5 yamiiile27@hotmail.com \\ 2Facultad de Químico Biológicas de la Universidad Autónoma de Campeche. Av. Agustín Melgar entre Juan \\ de la Barrera y Calle 20. C.P. 24039. San Fco. De Campeche. ${ }^{2}$ mcvalenc@uacam.mx
}

The fruit flies of the Tephritidae family, represent one of the most important agricultural pests in the world, besides causing a great economic impact due to losses in a great diversity of fruits and other vegetables limit the development of agriculture in many countries and are the direct cause of a considerable number of quarantines and restrictions imposed by the importing countries, causing a detriment in the economy of fruits producing countries (Antonio-Hernández and García-Ramírez, 2017). However, in Mexico the knowledge of its hosts is generally restricted to Anastrepha species of economic importance, while studies on the relationship of other species of this genus with their host plants are poorly understood.

Manuscrito recibido el 30 de enero de 2018, aceptado el 20 de marzo de 2018. 
Anastrepha ampliata it's a species that belongs to the fraterculus group, described with specimens from Mexico and Guatemala (Hernández-Ortíz, 1990). In Mexico, it is distributed in tropical zones with warm climates in the states of Campeche, Chiapas, Jalisco, Quintana Roo and Yucatan (Hernández-Ortíz, 2007). It's a species commonly collected in the Yucatan Peninsula in multilure traps, and before the publication of this note, the aspects of its biology remained unknown.

The fruit collection was carried out in the month of July 2017, in the community of "El Ramonal", which belong to the municipality of Escarcega, Campeche (18³6'24.30"N 90²4 '04.06"W) in an ecosystem belonging to subperennifolia medium forest. Ripe fruits of Vitex gaumeri Greenm (Verbenaceae) were collected directly from the ground; the botanical material was placed in a plastic container $(20 \times 30 \mathrm{~cm})$ and transported to the entomology laboratory of the Escuela Superior de Ciencias Agropecuarias, Universidad Autónoma de Campeche (ESCA-UAC). A total of 72 fruits were collected, weighed in an analytical balance (LG-A, Mod. 501A) and dissected. Fruits had an average of $5.9 \mathrm{~g}$, and a total weight of $425 \mathrm{~g}$. A total of 28 larvae were found feeding on the mesocarp of 25 fruits, 22 of them had one larva and in three fruits were found two. Larvae were placed in a transparent plastic pupation chamber of cylindrical shape $(15 \mathrm{~cm}$ in diameter $\times 30 \mathrm{~cm}$ high) a $10 \mathrm{~cm}$ thick vermiculite layer was added as substrate to favor the pupation and finally, the upper part was covered with a fine mesh cloth to allow aeration.

One week later (July 24), the pupation chamber was inspected, and 16 pupae were recovered and placed individually in small plastic containers $5 \times 5 \mathrm{~cm}$ and checked daily until the adults emerged. Between August 8 and 9, seven specimens of A. ampliata emerged (five females and two males), which were left in the pupation vessels for 24 hours, to complete their morphological development. The specimens obtained were identified by Enrique Antonio-Hernández, placed in plastic microvials $(4 \times 0.5 \mathrm{~cm})$ containing alcohol $(70 \%)$ and deposited in the entomological collection of the ESCA-UAC.

Vitex gaumeri is a tree of unknown origin, locally called in the Yucatan peninsula and Central America by the name of Yax-nik (Benavides, 1994), it is used in traditional medicine (leaves), has a use as timber, a height between 25-30 m, light brown bark, flowers (4-5 mm long) in blue-violet clusters and green fruits (1-2 cm wide), rounded, and sweet tasting.



Fig. 1. a) Infested fruits of V.gaumeri, b) female specimen of A. ampliata emerged from fruits, lateral view. 
Prior to this report, V. gaumeri had not been reported as feeding plant for the genus Anastrepha, however, some species of Verbenaceae have been reported as a host plant of this genus, such is the case of Anastrepha amita Zucchi that in Brazil has as a host plants two species of the genus Citharexylum; Citharexylum myrianthum Cham (Souza-Filho et al. 1999) and Citharexylum poeppigii Walp. (Marsaro et al., 2010), likewise, this species has been found infesting Duranta erecta (Custodio et al., 2016); on the other hand, like the previous species, Anastrepha distincta has been reported feeding during its larval stage on C. poeppigii Walp (Marsaro et al, 2010); and recently, Anastrepha durantae Norrbom was described from specimens obtained in fruits of Duranta peruviana Moldenke in Peru (Norrbom et al., 2015). With the present report, there are five known of Verbenaceae species, included in three genera, which are used as feeding plants of four Anastrepha species belonging to the fraterculus group.

\section{REFERENCES}

1. Antonio-Hernández E. y M.J. García-Ramírez, 2017. Primer registro de Anastrepha canalis Stone, 1942 (Diptera: Tephritidae) en Turpinia occidentalis (Sw.) G. Don, 1832 (Staphyleaceae) en México. Entomología Mexicana, 4: 487-490.

2. Benavides J.E., 1994. Árboles y arbustos forrajeros en América Central vol.2. Programa de agricultura sostenible. Informe técnico CATIE No. 236.

3. Custódio A.C., T.L. Donnaruma, M.F. Souza-Filho, L.R.F. Louzeiro y A. Raga, 2016. Moscas-dasfrutas (Diptera: Tephritidae, Lonchaeidae) associadas as suas plantas hospedeiras no estado de São Paulo. Biológico, São Paulo, v.78, n.2, p.36-,jul./dez., 2016.

4. Hernández-Ortiz V., 1990. Lista preliminar de especies mexicanas del género Anastrepha (Diptera: Tephritidae) con descripción de nuevas especies, registros y sinonimias. Folia Entomológica Mexicana, 80: 227-244.

5. Hernández-Ortiz V., 2007. Diversidad y biogeografía del género Anastrepha en México. En: Hernández-Ortíz V. (Ed). Moscas de la fruta en Latinoamérica (Diptera: Tephritidae): Diversidad, biología y manejo. S y G Editores, Distrito Federal, México.

6. Marsaro Jr. A.L., R.A. Silva, W.R. Silva, C.R. Lima, A.S. Flores y B. Ronchi-Teles, 2010. New records of Anastrepha (Diptera: Tephritidae), its hosts and parasitoids in the Serra do Tepequém, Roraima state, Brazil. Revista de Agricultura (Piracicaba), 85(1): 15-20.

7. Norrbom A. L., E.J. Rodríguez, G.J. Steck, B.A. Sutton y N. Nolazco, 2015. New species and host plants of Anastrepha (Diptera: Tephritidae) primarily from Peru and Bolivia.

Zootaxa, 4041(1): 001-094.

8. Souza-Filho M.F., Raga A., Canal R.A. y Zucchi R.A., 1999. Anastrepha amita Zucchi (Dip., Tephritidae): primeiro registro hospedeiro, nível de infestação parasitóides associados. Arquivos Do Instituto Biologico (Sao Paulo), 66: 77-84. 
BIOCYT Biología, Ciencia y Tecnología, se encuentra actualmente indexada en
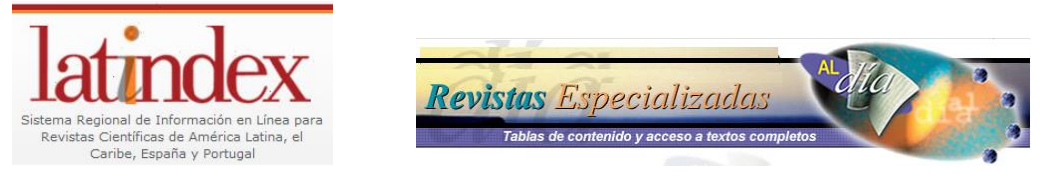

O Dialnet

\section{Actualidad Iberoamericana}
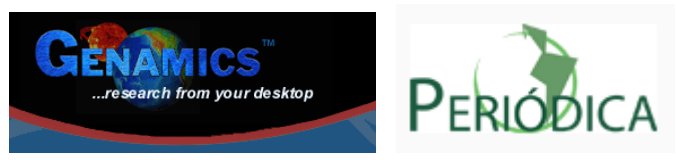

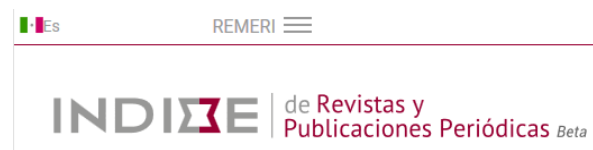

alojada en los repositorios


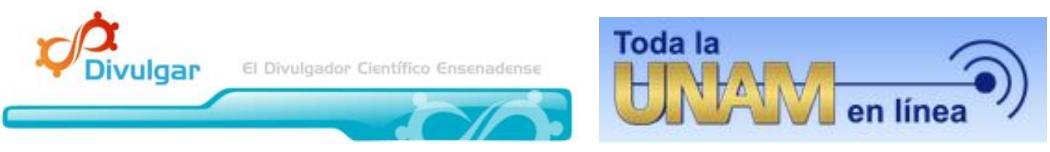

y en bases electrónicas de bibliotecas

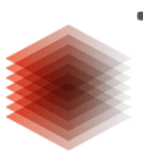

TIB

LEIBNIZ-INFORMATIONSZENTRUM

TECHNIK UND NATURWISSENSCHAFTEN
UNIIVRSITÖTSBIBLIOTHEK 